\title{
The Paradigms of Consciousness: A Discourse
}

\author{
Khalidah Khalid Ali ${ }^{1 *}$ Muhaimin bin Sulam² \\ ${ }_{1,2}$ Department of Management and Humanities, Universiti Teknologi PETRONAS, 32610, Seri Iskandar, \\ Perak Malaysia
}

\begin{abstract}
Consciousness is deep in meaning and utilised in many different ways. It is often used to scientifically explain one's ability to discriminate stimuli, report information, monitor internal states or control behaviour. This paper investigates the concepts and paradigms of consciousness from scientific, Western and religious perspectives with focus on Islamic dimensions as a discourse. A library research is conducted and online resources are utilised to review literatures from multi-disciplines before arriving at a conclusion. Discursive paradigms of consciousness recognise it as an abstract concept. Consciousness is beyond cognition. While cognitive thoughts, theories and ideologies relate consciousness to the five senses of humans, the concepts of 'will', awareness (i.e. being aware of things happening around a human being) and having a sense of purpose or intent in undertaking actions are relevant in the study of consciousness. A conscious person will use his/her senses to conduct life as civilised beings. However, by linking the body and the soul in explaining consciousness from Islamic viewpoints, consciousness is the awareness of oneself driven by his/her commitment and conviction as a servant of God and total submission to the Creator. Consciousness from Islamic contexts indeed relates to iman (faith) and taqwa (God consciousness).
\end{abstract}

Keywords: Consciousness, Multi-disciplines, Islamic perspectives, Discourse.

\footnotetext{
*Corresponding author: khalidah_kh@utp.edu.my
} 


\section{Introduction}

This paper is part of a doctoral work to study the consciousness of ethics among the Malay ethnic group in Malaysia embracing Islam as a religion. As a discourse, it will firstly investigate the concepts and paradigms of consciousness from scientific, Western and religious perspectives before focussing on Islamic dimensions in order to put in context with the above-mentioned full research study.

The word 'consciousness' is deep in meaning and utilised in many different ways. It is often used to scientifically explain one's ability to discriminate stimuli, report information, monitor internal states or control behaviour (Chalmers, 2002). In definition, it is the state of being awake and aware of one's surroundings (Oxford Dictionaries online, 2016). Consciousness is also defined as the quality or state of being aware especially of something within oneself (Merriam Webster Online Dictionary, 2017). Rationally, consciousness is a process in itself. As such, it is the sum of all system interaction, that is, the processes that finally may lead to a conclusion about the awareness of the surrounding or self. Consciousness, being defined as awareness, however, does not necessarily require reason, reasoning or rationality. Even an unreasonable and irrational man has consciousness from relativistic contexts.

Following a medical definition which often emphasises on objectivity and scientific viewpoints, consciousness is being aware of the stimulants through the five human senses, consistently alert and controlling one's behaviour and attitudes. In other words, what is meant by consciousness is one's ability to perceive through senses.

By examining this concept within philosophy, one form that definitions of consciousness may take is in the description of the phenomenal, experiential state in which a person is (Kriegel, 2006). Complementing earlier definitions, consciousness is the subjective experiencing of a stimulus or mental state. This state has been referred to as qualia by William James (1890) and has received a significant amount of attention from philosophers (Chalmers, 2002) who often use the above term (singular 'quale') to refer to the introspectively accessible, phenomenal aspects of our mental lives. In this broad sense of the term, it is difficult to deny that there are qualia. Disagreement typically centres on which mental states have qualia, whether qualia are intrinsic qualities of their bearers, and how qualia relate to the physical world both inside and outside the head. The status of qualia is hotly debated in philosophy largely because it is central to a proper understanding of the nature of consciousness. Qualia are at the very heart of the mind-body problem (For more elaborations, refer to http://plato.stanford.edu/entries/qualia/, retrieved online on 6 September, 2015).

While qualia have been discussed above, the concept of philosophical consciousness for man means 'being aware of his existence'. There exists, to a certain extent, willpower in consciousness; that influences one's decisions (Chalmers, 2002). After a human perceives things with his or her five senses, the brain processes the information that is sent to it and this consequently results in the direction of the decisions it (the brain) makes. In consciousness, to be able to conduct 'the behaviour directed toward the purpose' is in question.

To think about thought, which is the activity of high consciousness, is a characteristic of man (Chalmers, 2002). Consciousness, which is expressed through the word 'cognition', therefore is the mental activity and high brain functions that concern the processes of thought, decision-making and attention of a person. It is consciousness that directs the processes which can be summarised as 'quest for meaning with the perception of time and existence'. Man is a special being with intelligence and ability to distinguish between right and wrong; good and bad by relating to situations. This consciousness, which makes man 'real man', has high functions and it means being able to discern and differentiate abstract concepts.

\section{Theories of Consciousness: An Overview}

Consciousness theories are often divided into physicalist and anti-physicalist theories (Kriegal, 2006). Physicalist theories attempt to account for phenomenal consciousness in (micro) physical terms whereas anti-physicalist theories claim that it is impossible to account for phenomenal consciousness. A scholar, Uriah Kriegel (2006a), views that a more fundamental division for theories of consciousness is reductive and non-reductive theories. Reductive theories attempt to account for phenomenal character in non-phenomenal terms whereas non-reductive ones do not. Whether the relevant terms can in turn be accounted for in (micro) physical terms or not is left as an open question at this stage (Kriegal, 2006b). 
Although most philosophical works have concentrated on reductive theories, some scholars have devoted to non-reductive ones as well. By claiming that phenomenal consciousness cannot be reductively accounted for in non-phenomenal terms, a non-reductive theory treats phenomenal consciousness as a pertinent feature of the world. It thus considers that there are (at least) two fundamental kinds of features in the world-physical and phenomenal. For this view and reason, it is referred to as 'dualism' (Latin word for two). In addition to the above classifications of consciousness theories, there are also higher order theories of consciousness. They include Higher Order Perception Theory and Higher Order Thought Theory by actualists; Higher Order Thought Theory by dispositionalists; and Self-Representational Higher-Order Theories (See Stanford Encyclopaedia of Philosophy, Higher-Order Theories of Consciousness. Accessed from http://plato.standford.edu/entries/consciousness-higher, on 24 May, 2016).

All these theories (somewhat similar to cognitive theories in general), assume that the right level at which to seek an explanation of phenomenal consciousness is a cognitive one; providing an explanation in terms of some combination of causal role and intentional content. To elaborate, all such theories claim that phenomenal consciousness consists of certain kinds of intentional or representational content figuring in certain distinctive positions in the causal architecture of the mind (Stanford Encyclopaedia of Philosophy).

Some Western scholars such as Kirk (1994), Dretske (1995) and Tye (1995) claim that for a state to be conscious in the relevant sense is for it to be poised to have an impact on the organism's decision-making processes, perhaps also with the additional requirement that those processes should be distinctively rational (Block, 1995). Interestingly, the main motivation of higher order theories of consciousness derives from the belief that all (or at least most) mental-state types are both of conscious and unconscious varieties.

While attempts are made to highlight some consciousness theories, this paper will continue to delve into the concept of consciousness from multidisciplinary approaches (including social science, humanity, psychology and religion) before finally discussing its paradigms from Islamic dimensions.

\subsection{Consciousness from Multidisciplinary Perspectives}

Discussing consciousness from societal perspectives within rational thoughts, Berger and Luckmann (1966) in their Social Construction of Reality logically argue that the objective social reality, although produced in social action, appears to the individual as separate and independent from him or her. The subjective side consists of the consciousness an actor has, shaped in pervasive processes of socialisation, and sustained and modified in daily interactions (Eberle, 1992). Society must be grasped in its duality as an 'objective' and a 'subjective' reality. Berger and Luckmann further explained that persons and groups interacting in a social system create, over time, concepts or mental representations of each other's actions, and that these concepts eventually become habituated into reciprocal roles played by the actors in relation to each other. Berger and Luckmann's sociology of knowledge works have also introduced the term 'social sciences'. Their studies were strongly influenced by the work of Alfred Scultz (1899-1959), an Austrian social scientist whose works bridged sociological and phenomenological traditions to form a social phenomenology.

Next, in the rubric of consciousness within social sciences, C. Wright Mills (1916-1962), in The Social Imagination (1999) deliberates on how social science should be pursued and advocated for a humanist sociology connecting the social, personal and historical dimensions of human lives (Elwell, 2013). Mills sees links between the apparently private problems of the individuals and important social issues within one's consciousness. In his vision, Mills has in fact proposed the proper relationship in sociological scholarship between biography and history within his own self-consciousness to enhance socialisation processes in the 'classy' and differentiated American society during his time.

Interestingly, another Western scholar, Teun A. Van Dijk (1998), in his book, Ideology - a multidisciplinary approach, while discussing on the social dimensions of ideologies, linked consciousness with the cognitive context, very much related to the history of the study of ideologies since Marx and Engels. However, he recognised that this form of consciousness is mostly 'false consciousness.

False consciousness here means group ideologies that do not reflect the 'objective' socio-economic interests of a group (Van Dijk, 1998). "Thus, workers or poor people may develop an ideology that is rather in the interests 
of, respectively, the ruling class, the elites, the company they work for, or the owners or managers of that company" (Van Dijk, 1998 pp. 96).

Van Dijk explicitly advocated 'consciousness' as 'awareness'. However, he views that although the notion of 'consciousness' may be clear in its everyday sense, it is theoretically hardly explicit. Being conscious of, being aware or realizing something, first of all, is a 'state of mind' (Van Dijk, 1998 pp. 98). Hence, 'consciousness' is again defined with concepts like 'awareness', which is present in man through metacognition genes. Van Dijk further theorised 'consciousness' into many types or grades i.e. between totally explicit awareness and knowledge on one hand, and largely implicit knowledge and 'mere' use as 'lived experience' on the other hand. "The distinction is socially often associated with 'ideologues' and the 'masses', a distinction we need to analyse as part of the social analysis of ideologies" (Van Dijk, 1998 pp. 99). The chapters that follow Van Dijk's Consciousness chapter (Chapter 9) further examine on inter-related issues such as common sense, knowledge and truth, identity and social cognition.

Following Van Dijk's line of cognitive thoughts and grasping on earlier important indicators such as using the five traditionally recognised human senses (i.e. sight, hearing, taste, smell and touch), the concepts of 'will', awareness and being aware of things happening around a human being and having a sense of purpose for doing something, we may deduce that a conscious person will use his/her senses to conduct life as civilised beings.

While Van Dijk (1998) views consciousness as theoretically hardly explicit, another Western scholar, Jerry Foss (2000, pp. 4) openly admits that consciousness is a riddle. His works attempted to link the objective concept of science with the subjectivity of consciousness which he later referred to as the science of consciousness. He advocated that there are two main ways of understanding the world: the manifest model and the scientific model. The manifest model is the original representation of the world generated for each human being by the natural senses inherited from human evolutionary history. The scientific model, on the other hand, is a more sophisticated representation of the world generated for people in general, employing instruments and inference; the product of acquired systems that humans inherit from cultural history. The manifest model is privileged as it is the ultimate interface with reality; both as a human being and for scientific models. Conversely, there is power in the scientific model since it has increased the scope and depth of human knowledge. When the relationship between the two is functioning well, it achieves complementarity. The difficult relationship between manifest and scientific models gives life to the riddle of consciousness (Foss, 2000, pp. 1). Needless to say, his works may be useful for scientists working on cognitive science, if not for philosophers to understand consciousness from theoretical and modelling constructs.

Nevertheless, as much as substantial work has been done on consciousness in the West, more seem to agree that consciousness is the object of psychology (Struthers, 2001). While psychology has focused on consciousness, again scholars have viewed that it is a slippery term and many have attempted to formulate a coherent description of what consciousness represents (Struthers, 2001). In fact, American psychologist, William James (1890) avoided explicitly in defining consciousness. He believed that humans are all similar with consciousness through introspection; it is a self-evident phenomenon requiring no operational defining (Struthers, 2001). To quote Struthers' words, "It is this introspective technique which was used to excess by many early psychologists that, in part, led to a reactionary movement by the behaviourists." Later in his life, however, James changed his position, arguing that consciousness was a non-entity and had no place as an object of empirical investigation (Jaynes, 1978).

Another prolific psychologist, Sigmund Freud (1912) thoroughly explored the human mind and views that, "the conscious mind may be compared to a fountain playing in the sun and falling back into the great subterranean pool of subconscious from which it rises." Freud relates consciousness with the human mind and thought, action and interaction. Freud's notion of unconscious mentality is arrived at by pressing the distinction of the mental states from consciousness and combining it with the topographical model where all the psychological locales are spoken of as existing independently from their members at any given moment (De Sousa, 2011; Freud, 1915; Freud, 1937).

Freud's notion may be interpreted in terms of gaps in self-explanation. Freud believed that when we explain our own behaviour to ourselves or others (conscious mental activity), we rarely provide a true account of our motivation. This behaviour no doubt does not relate to lying, but although humans are deceivers of others; they are even better at self-deception. One's rationalisations of his/her conduct are therefore disguising or concealing the reasons. Freud's life work was dominated by his attempts to find ways of penetrating this often indirect and elaborate façade that obscures the hidden structure and processes of personality. Freud founded psychoanalysis, 
(i.e. a method for treating mental illness and also a theory explaining human behaviour) which regarded the entire mental being in the first place as unconscious, and hence for them (especially psychotic cases), consciousness might be present or absent. However, it is important that one understands the nature of the unconsciousness in broad holistic terms rather than the fine details that Freud gave, and also one must follow the coherence or logic of such a concept to understand the present day understanding of consciousness (Freud, 1912; Ricoeur, 1970; De Sousa, 2011).

The elaborative discussions have so far outlined the concept of consciousness from multidisciplinary approaches (i.e. from medical sciences, philosophy, social science, humanity and psychology) based on several significant works of Western scholars. Much as the above studies have attempted to outline the concept of consciousness, it is well-said that consciousness is an abstract concept that is beyond human experiments (James, 1890; Struthers, 2001).

Accepting the fact that consciousness is an implicit, abstract and a slippery concept and recognising the contributions of Western scholars from rational judgements, one issue remains to be answered. Why is it that even from these definitions and elaborative explanations from rational thoughts, conscious people still commit unethical and false acts? Rational thoughts have its limitations. Therefore, in order to answer this challenging question, discussions are engaged within religious perspectives to understand deeply the meaning of consciousness.

The author shall briefly explain from the viewpoint of Christianity, followed by Buddhism and Hinduism before dwelling in detail on how Islam views consciousness to put in context with the research study i.e. the consciousness of the Malay community on ethics.

Recognising consciousness as an object of psychology (Struthers, 2001), the words of Struthers (2001) is quoted as follows: "Christianity places an emphasis to study consciousness as the locus for decision-making and establishing relationships is significant for Christians in psychology, cognitive science, and neuroscience because these two abilities are near the heart of the Christian experience. While scripture has little to say about the link between the mind and the brain, the nature of the 'stuff that it is made of', or the architecture of mental life, it does highlight our mental life as an integral part of our relationship with Christ” (Hunt, 1995). In short, Christianity views consciousness as a link to Jesus Christ while embarking on studies within the psychology discipline. On the other hand, Buddhism views consciousness (i.e. vijnana) as life force, mind or discernment. It relates to the six internal bases i.e. the eye, ear, nose, tongue, body and mind and six external sense bases i.e. visible forms, sound, odour, flavours, touch and mental objects. Hence, sense specific consciousness arises and is dependent on an internal and an external sense base (Thanissaro, 1998).

Interestingly, Hinduism relates consciousness as to know God distinctly by realising His Existence through an intuitive experience and to speak to Him intimately (Swami Nikhilananda, 1985). What do Muslim scholars have to say about consciousness?

\subsection{Consciousness from the Islamic Perspective}

An Islamic scholar, Nevzat Tarhan (2012), in his explanation on consciousness, relates humans to their nature and role on earth. "Man, is a being that adds meaning to everything and that is aware of his existence. Consciousness is one of the properties that distinguishes man from the other living beings and the most important and distinct property forming the difference that distinguishes him from the other species. Consciousness is a step between spirit and body."

Consciousness, hence, is more than cognition. It appears that in order to relate the concept of consciousness from Islamic thoughts, one has to understand the creation of man in itself. Consequently, this paper will explore on Islamic thoughts to understand the nature of man in order to link with consciousness within Malay-Muslim and Islamic contexts to relate to the full doctoral study.

Among all creations in the heaven and earth, only man has been bestowed with many distinctive qualities (Mohd Abbas, 2011). Allah has created man as the best creation and gave him cognitive and reflective abilities as well as intelligence ( ' $a q l$ ) and heart ( $q a l b)$ to distinguish between good and evil (Khalidah et al., 2014, pp. 362). As the recipient of these distinctive qualities from Allah the Almighty, man is placed on the highest pedestal in the hierarchy of creations. Some of these distinctive features are: man has been created in the best of forms 
(The Quran, At-Tin, Verse 1-4), provided with creative intelligence (The Quran, Al Baqarah Verse 31-34), and given the power of speech and freedom of choice (The Quran, Ar- Rahman, Verse 4; The Quran, Al-Insan, Verse 3) (Refer to Mohd. Abbas, 2011 and Azfalur Rahman, Muhammad, 1988).

Because of his special creation, man is chosen to be Allah's khalifah (vicegerent) on earth. Man has been further honoured in his stature and position when Allah made all things created in the heaven and earth to be of service to him (The Quran, At-Jathiyah, Verse 13; Al-Isra', Verse 70) (Refer to Mohd Abbas, 1997). Therefore, he is expected to be self-conscious and be an ethical human being, following the rules of the Quran and the Sunnah due to his noble position in the sight of Allah, the Creator.

"We have indeed created man in the best of moulds."

(The Quran, Surah At-Tin, Verse 4)

In Islam, man is born with fitrah (i.e. primordial nature). In Arabic language, though diverse in meanings, alfitrah also explains that man comes to this world without any stain of sin (Mohd Abbas, 2011). However, the concept of alfitrah is not in congruence with the principle of the 'Original Sin'as espoused in Christianity (Note: Original sin is an Augustine Christian doctrine which views that everyone is born sinful. This means that they are born with a built-in urge to do bad things and to disobey God. It is an important doctrine within the Roman Catholic Church. The concept of Original Sin was explained in depth by St Augustine and formalised as part of Roman Catholic doctrine by the Councils of Trent in the 16th Century. Original sin is not just this inherited spiritual disease or defect in human nature; it is also the 'condemnation' that goes with that fault. (Sourced from http://www.bbc.co.uk/religion/religions/christianity/beliefs/originalsin_1.shtml, accessed on 10 October, 2015).

In the Quran, alfitrah explains that man has been born as a believer in Allah the Almighty (The Quran, Surah Ar-Rum, Verse 30). Nevertheless, parents have a primary role to ensure that their children are shaped with aqidah (firm belief/I'tiqaad), akhlaq (good character/ethics), and adab (good manners/morals). William H. Shaw (2008, pp. 12) has rightly emphasised that upbringing is the first critical factor influencing one's ethical values which is manifested from internalisation and self-consciousness (Khalidah et al., 2014, pp.4-5). The pertinent role of parents in the upbringing of their children have also been duly recognised in Islam based on a relevant Quranic verse,

"O ye who believe! Save yourselves and your families from a Fire whose fuel is Men and Stones, over which are (appointed) angels' stern (and) severe, who flinch not (from executing) the Commands they receive from Allah, but do (precisely) what they are commanded."

(The Quran, Surah At-Tahriim, Verse 6)

Further exploration of The Holy Quran reveals the dual nature of man: his body and his spirit (ruh). This fact well supports and confirms Nevzat Tarhan's writings on consciousness, earlier discussed in this paper. Relating to this too, The Quran further explains that after creating Adam, Allah breathed into him His spirit:

"Behold! Thy Lord said to the angels: "I am about to create man, from sounding clay form mud moulded into shape; "When I fashioned him (in due proportion) and breathed into him of My spirit, fall ye down in obeisance unto him."

(The Quran, Surah Al- Hijr, Verse 28-29)

These verses further justify that man's conscience is felt from both his body (through the senses) and his spirit; that is his soul. These facts well support and confirms Nevzat Tarhan's writings on consciousness, earlier discussed in this discourse. Hence, it is appropriate to regard consciousness as a step between man's body and his ruh or spirit (Nevzat Tarhan, 2012), an immortal feature that is indeed beyond human explanation. Aptly, it is the ruh that leaves the human body upon death (Mohd Abbas, 2011); hence, he/she is no more conscious! Within consciousness, man, being made the most honoured and best creation of Allah, is also entrusted with the Amanah (trust) from Allah. 
"We did offer indeed the Trust to the Heavens and the Earth and the Mountains: but they refused to undertake it, being afraid thereof: but man undertook it-he was indeed unjust and foolish."

(The Quran, Surah Al-Ahzab, Verse 72)

Amanah can be referred to as reason, intellect or the faculty of volition (Muhammad Asad, 1980; Mohd Abbas, 2011). Amanah can also be related to power and authority granted to man through his role as a vicegerent. Holistically, amanah may mean the sum total of all the decrees, commands (amr) and prohibitions (nahi) present in the Shariah (Afzalur Rahman,1988). This relates to amar maruf nahi mungkar i.e. promoting goodness and forbidding evil acts by religiously following the rules in The Quran and the Sunnah (The traditions of Prophet Muhammad SAW). Indeed, The Quran has revealed that humans are trustees of Allah. Hence, they have no choice but to be conscious of their role and display virtues such as honesty, trustworthiness and integrity while executing their responsibilities because they will be accountable for all their actions in this world and the hereafter (Syed Othman and Aidit, 1994; Khalidah et al, 2014).

There is another Islamic concept related to the nature of man as a special being, i.e. mithaq or covenant. Man has been granted the covenant by His Lord. Aptly, there is a contract between man and His Creator. Through this contract/agreement, humans as a whole have accepted Allah to be their Lord and Cherisher while they were in the form of spirits in Lauh Mahfodz. This contract between man and his Lord has been made long before he was born into this world (Refer to the Quran, Surah Al- A'raf (8:172). The content of this covenant is retained in the sub-conscious mind of man as potentiality that can be brought to consciousness (Mohd. Abbas, 2011; Afzalur Rahman, 1988).

Next elaborating on mithaq (i.e. the 'covenant'), interestingly, a Muslim scholar, Afzalur Rahman (1988) views that factors such as type of education, social environment and other influences could never totally efface or tarnish the covenant from coming to the conscious part of the human being. In spite of the perversion/misinterpretation and prevention caused by wrong education and negative social influences, the covenant as a commitment/contract lays embedded in the sub-conscious mind of man and it will emerge to reality in response to positive external factors (Afzalur Rahman,1988; Mohd. Abbas, 2011) that have always invited humanity to the remembrance of the covenant. Some of these factors are the prophets, heavenly books, inviters to the truth from among the followers of the prophets, good social environment, proper and correct education and so forth (Afzalur Rahman, 1988; Muhammad Asad, 1980, pp. 9-10).

In Arabic, 'nur' or light means knowledge. Knowledge is sourced from many channels including education and media through cognition. Knowledge opens to one's awareness and understanding on a subject matter. From behavioural and rational viewpoints, knowledge will consequently lead to practice, application and internalization as manifested by the consciously positive behaviours of ethical beings. Knowledge certainly contributes directly to human civilisation and wellbeing with practice and internalization. The works of Nasr (1981) has explored humanity's quest for knowledge and quest for the Divine and how these quests relate to one another throughout history. The importance of knowledge has also been discussed by Mahathir Mohamad in his book, The Challenge (1986) while linking Islam with the Malaysian Malay society and evolving capitalistic and liberal global trends.

However, several questions remain to be answered. Despite the covenant and knowledge, why are some people not conscious of the contract? Why are humans committing unethical acts despite having knowledge? Are they not conscious that they are accountable for their actions, be it good or bad, because of the covenant; the contract? As much as there are no concrete answers to these questions, they may be partly answered by differentiating between a conscious person and a knowledgeable person from Islamic viewpoints. A conscious person will know his role from Allah's sight. In contrast, a knowledgeable person need not necessarily be conscious in a true sense if he does not apply and internalise his knowledge and act virtuously with conviction in life. Quoting and translating from the words of Pahrol Md. Juoi, a Malaysian Malay scholar, "a knowledgeable person need not necessarily be conscious. However, a conscious person knows who he or she is; a servant to the Creator. As a servant, he/she is obligated to follow Allah's rules religiously." The Malay version of the translated quote reads, "Seseorang yang tahu, dia tak semestinya sedar, tetapi bagi seseorang yang sedar, dia tahu siapa dia; seorang hamba Allah yang akan ikut perintahNya secara menyeluruh" (IKIM.fm in the segment, Indah Itu Indah).

To summarise, as much as the West has noted that 'consciousness' is a phenomenal concept, it is also implicit from Islamic viewpoints. Consciousness relates to other Islamic concepts such as khalifah, al-fitrah, ruh, amanah and mithaq (i.e. covenant). In fact, consciousness in Islam relates to the heart and soul. It appears that in order to be virtuously conscious beings, one has to develop his spirit that begins from a clean and good heart. The term 'heart' has different and multi-level connotations in the Islamic tradition. It is not simply the organ of emotions, 'feelings' and desires, or decisions and opinions, but goes to encompass the soul, knowledge, bravery and more. 
When purified, it is the seat of the intellect, i.e. the ray of the Divine within the creatures (http://www.livingislam.org/m/qalb_e.html accessed on 12 October, 2015). As professed by Prophet Muhammad (saw), "Truly in the body, there is a morsel of flesh, which, if it is sound, all the body is sound and which, if it be diseased, all of it is diseased. Truly it is the heart" (Hadith by Imam Nawawi). Imam Nawawi said, "This hadith was used as proof that the seat of the mind is in the heart (al- 'aql fi al-qalb) and not the head" (http://www.livingislam.org/m/qalb_e.html, accessed on 12 October 2015). A good heart therefore leads to a good soul with high consciousness to do good deeds as ethical beings.

\section{Conclusion}

This paper has attempted to conceptualise and deliberate on the paradigms of consciousness as a discourse. It has investigated consciousness from scientific and Western perspectives, multi-disciplines and religion with a focus within Islamic contexts. Discursive paradigms of consciousness recognise it as an abstract concept. Consciousness is aptly beyond cognition. While cognitive thoughts, theories and ideologies relate consciousness to the five traditionally recognised human senses, (i.e. sight, hearing, taste, smell and touch), the concepts of 'will', awareness (i.e. being aware of things happening around a human being) and having a sense of purpose or intent in undertaking actions are relevant in the study of consciousness. It may be deduced that a conscious person will use his/her senses to conduct life as civilised beings. However, by linking the body and the soul in explaining consciousness from Islamic perspectives, consciousness is the awareness of oneself driven by his/her commitment as a servant of God and total submission to the Creator. Consciousness from Islamic contexts indeed relates to iman (faith) and taqwa (God consciousness).

\section{References}

Al Quran, King Fahd Complex: Madinah Munawawarah, K.S.A. For the Printing of the Holy Quran; www.qurancomplex.org

Azfalur Rahman, Muhammad. (1988). Encyclopaedia of Seerah Vol. 6 London: Seerah Foundation, pp1.

Berger, P.L. and Luckmann, T. (1966). The Construction of Reality, Garden City, New York: Anchor Books, 1966, pp.51-55, 59-61. Accessed from www.cf.a.c.uk/socsi/underg on 2 November 2015.

Block, N. (1995). 'A confusion about a function of consciousness,' Behavioral and Brain Sciences, 18: $227-247$.

C. Wright Mills. (1999). The Sociological Imagination (1916-1962), Oxford University Press. Accessed from https://global.oup.com/academic/product/the-sociological-imagination-9780195133738?cc=my\&lang=en\&

Chalmers, D. J. (2002), Consciousness and its Place in Nature, Published in (S. Stich and F. Warfield, eds), Blackwell Guide to the Philosophy of Mind (Blackwell, 2003), and in (D. Chalmers, ed) Philosophy of Mind: Classical and Contemporary Readings (Oxford, 2002).

De Sousa, A. (2011), Freudian Theory and Consciousness: A Conceptual Analysis. In: Brain, Mind and Consciousness: An International, Interdisciplinary Perspective (A.R. Singh and S.A. Singh eds.) MSM, 9 (1), pp. 210-217. Unpublished work

Dretske, F. (1995). Naturalizing the Mind. Cambridge, MA: MIT Press.

Eberle, Thomas S. (1992). A new paradigm for the sociology of knowledge: "the social construction of reality" after 25 years. In: Schweizerische Zeitschrift für Soziologie 18 (1992), 2, pp. 493-502. URN: http://nbnresolving.de/urn:nbn:de:0168- ssoar-24182

Elwell, F.W. (2013). "C. Wright Mills on the Sociological Imagination," Retrieved Feb 21, 2018. From http://www.faculty.rsu.edu/ felwell/Theorists/Essays/Mills3.htm 
Foss, J. (2000). Science and the Riddle of Consciousness - A Solution, USA: Kluwer Academic Publishers, pp.14.

Freud, S. (1912). In: Totem and Taboo, James Strachey, translator. London: Hogarth Press, Standard Edition.

Freud, S. (1915). In: The Unconscious. James Strachey, translator. London: Hogarth Press; Standard Edition.

Freud, S. (1937). In: An Analysis Terminable and Interminable. James Strachey, translator, London: Hogarth Press; Standard Edition

Hunt, T. W. (1995), The Mind of Christ, Nashville, TN: Broadman \& Holman Publishers.

James, W. (1890). Classics in the History of Psychology. Classics in the History of Psychology. An internet resource developed by. Christopher D. Green. York University, Toronto, Ontario. (Return to index). Accessed from http://psychclassics.yorku.ca/James/Principles/prin4.htm.

Jaynes, J. (1978). The Origin of Consciousness and Breakdown of the Bicameral Mind, Cheektowaga, ON: University of Toronto Press, pp.1.

Khalidah Khalid Ali, Z. Ramly and T.C. Lau. (2014). Business Ethics, Shah Alam, Selangor, Malaysia: Oxford Fajar Publishing.

Kirk, R. (1994). Raw Feeling. Oxford: Oxford University Press.

Kriegal, U. (2006a). 'The same-order monitoring theory of consciousness,' in U. Kriegel and K. Williford (eds.) 2006.

Kriegal, U. (2006b). Consciousness, Theories of. Philosophy Compass 1/1 (2006): 58-64, 10.1111/j.1747-9991. 2006.00008.x

Mahathir Mohamad. (1986). The Challenge, Ipoh, Malaysia: Pelanduk Publications (M) Sdn Bhd. pp. 1- 4. 10, 17.

Merriam Webster Online Dictionary, 2017.

Mohd. Abbas Abdul Razak. (2011), Human Nature: An Islamic Perspective, Journal of Islam in Asia, Special Issue. No.1 March 2011 pp 251-274.

Mohd Abbas Abdul Razak. (1997), Human Nature: A Comprehensive Study Between Western and Islamic Psychology, Kuala Lumpur: IIUM, 1997. pp. 171-173.

Muhammad Asad (1980). The Message of the AlQuran, Gibralta: Dar al-Andalus.

Nezvat Tarhan. (2012, Dec. 12). Consciousness [Online]. Available: http://www. questions onislam.com/article/consciousness\#baslik2.

Oxford Dictionaries online, 2016

Ricoeur, P. (1970). Freud and Philosophy: An Essay on Interpretation, New Haven. Conn: Yale University Press.

Syed Othman Alhabshi and Aidit haji Ghazali. Islamic Values and Management. Kuala Lumpur, Malaysia: Inst. Islamic Understanding Malaysia (IKIM), 1994, pp.10.

Seyyed Hossein Nasr. (1981). Knowledge and the Sacred, Albany State Univ. of New York.

Swami Nikhilanada. (1985), The Gospel of Sri Ramakrishna, Ramakrishna- Vivekananda Centre, pp. 523 \&1225. 
Tye, M. (1995). Ten Problems of Consciousness. Cambridge, MA: MIT Press.

Thanissaro Bhikkhu. (Trans.) (1998). Chachakka Sutta: The Sixth Sextets (MN148). Retrieved 2007-06-17 from "Access to Insight."

The Holy Al Qur'an: Text, translation and commentary, Maryland: Amana Corporation, Abdullah Yusuf Ali, 1989.

Van Dijk, T. A. (1998). Ideology: A Multidisciplinary Approach. London: Sage Publications Ltd, pp. 96-97.

Struthers, W.M. (2001), Defining Consciousness: Christian and Psychological Perspectives, Perspectives on Science and Christian Faith 53, June 2001, pp. 102-106.

http://plato.stanford.edu/entries/qualia/, retrieved online on 6 September 2015.

http://www.brainyquote.com/quotes/quotes/s/sigmundfre403586.html\#LOV747K1c6TjQgRp.99, retrieved on 18 December 2015).

http://www.questionsonislam.com/content/nevzat-tarhan-profdr, on 31 September 2015.

http://www.bbc.co.uk/religion/religions/christianity/beliefs/originalsin_1.shtml, accessed on 10 October 2015.

http://www.livingislam.org/m/qalb_e.html on 12 October, 2015. 